\title{
Studi tentang implementasi komunikasi politik hukum Partai Keadilan Sejahtera (PKS) kabupaten Gowa
}

\author{
Muliaty Amin \\ Fakultas Dakwah dan Komunikasi UIN Alauddin Makassar \\ E-mail:aty.amin54@gmail.com
}

The main point of this research is that why the implementation of political communication of Partai Keadilan Sejabtera (PKS) is so important in Gowa regency. The goals of this research are to know PKS's existence in extending political communication particularly for people in Gowa regency. The field research is the method used in this research which is specifically qualitative-naturalistic-inquiry. The approach method used is sociology-historic-politic. The source of this research is all managers and members of Judgement Council Region of PKS in Gowa regency. The method for collecting data is observation, interview, dan documentation. The data validity in this research are done by credibility data checkup with persistent observation, triangulation, member check, and referential adequacy check. The outcome of this research points out that PKS's existence is displayed by its Perspectives, Missions, and objectives of PKS establishment. There are three factors influenced to vote or not to vote in National Election. At first is a party identity. Secondly is the capability of party in marketing campaign issue. The last is a candidate's performance. The communication ethic that is built by PKS in Gowa regency is that the communication ethic together with the internal elite party which is based on basic consideration and statute of PKS. Meanwhile, PKS's relation with people and components are established by either economic development or religion experience through Tarbiyah.

Masalah pokok yang diteliti dalam penelitian ini, adalah mengapa implementasi komunikasi politik sangat penting dalam PKS Kabupaten Gowa. Tujuan penelitian, adalah untuk mengetahui eksistensi PKS dalam mengembangkan komunikasi politik khususnya pada masyarakat di kabupaten Gowa. Metode penelitian yang digunakan, adalah filed research dengan jenis kualitatif-naturalistic inquiry (inkuiri alamiah). Pendekatan yang digunakan adalah sosiologis-historis-politis. Sumber data penelitian ini, pengurus dan anggota partai DPD PKS Kabupaten Gowa. Metode pengumpulan data dalam penelitian ini, adalah observasi, wawancara dan dokumentasi. Keabsahan data dalam penelitian ini, dilakukan melalui tahap pengecekan kredibilitas data dengan teknik perssistent observasion, triangulasi (triangulatiion), member check, dan referential adequacy cheks. Penelitian ini merumuskan kesimpulan bahwa eksistensi 
ljtihad, Jurnal Wacana Hukum Islam dan Kemanusiaan, Volume 15, No. 1, Juni 2015: 21-38

PKS digambarkan dalam Visi Misi, dan Tujuan pendirian PKS. Ada tiga faktor yang mempengaruhi untuk memilih atau tidak memilih dalam Pemilu. Pertama, identitas partai. Kedua, kemampuan partai dalam menjual isu kampanye. Ketiga, penampilan kandidat. Etika komunikasi yang dibangun oleh PKS di Kabupaten Gowa meliputi etika komunikasi dengan elit partai sendiri, yakni didasarkan pada anggaran dasar dan anggaran rumah Tangga PKS, sedang hubungannya dengan masyarakat dan anggota dibangun dengan melalui berbagai kegiatan baik dalam kaitannya dengan pembangunan ekonomi maupun yang berkaitan dengan pengamalan agama melalui tarbiyah.

\section{Keywords: Communication; Law Politics; Implementation; Partai Keadilan Sejabtera (PKS)}

\section{Pendahuluan}

Komunikasi politik hukum merupakan penyaluran aspirasi dan kepentingan politik rakyat yang menjadi input sistem politik hukum dan pada waktu yang sama menjadi penyaluran kebijakan yang diambil sistem politik hukum itu (Nimno, 2000: 22). Persoalan tentang komunikasi politik hukum sangat kompleks karena tidak semudah dengan politik hukum dan komnikasi. Persoalan itu muncul karena ada dua konsep yang mengusung disiplin komunikasi politik hukum, yakni konsep komunikasi dan konsep politik hukum. Suatu persoalan yang dikaji melalui bangunan dua bidang ilmu sering kali menimbulkan masalah dalam mengintegrasikan kedua konsep itu. Kalau bukan konsep komunikasi yang lebih dominan, maka sebaliknya konsep politik hukum yang dominan.

Upaya mempertemukan dua bidang ilmu yang berbeda, bukan pekerjaan mudah, namun hal itu tidak boleh mengurangi minat untuk mengkaji lebih dalam bidang studi yang sifatnya interdisipliner, karena memeiliki persentuhan dengan banyak bidang ilmu. Karena itu, komunikasi politik hukum perlu ditelaah mendalam yang mengacu pada studi interdisipliner, dibangun atas berbagai macam disiplin ilmu, terutama dalam hubungannya antara proses komunikasi dan proses politik hukum. Telaah seperti ini merupakan wilayah pertarungan dan dimeriahkan oleh persaingan teori, pendekatan, agenda, dan konsep dalam membangun jati dirinya. Karena itu pula komunikasi yang membicarakan tentang politik hukum, kadang diklaim sebagai studi tentang aspek politik dari komunikasi publik. Politik hukum adalah aktivitas untuk menentukan suatu pilhan mengenai tujuan dan cara-cara yang hendak dipakai untuk mencapai tujuan dalam masyarakat (Ahab, 1985: 71). Jadi politik hukum merupakan rangkaian asas prinsip, cara yang digambarkan untuk mencapai tujuan hukum, sehingga 
dapat dipahami bahwa politik hukum merupakan pengetahuan yang harus dipahami untuk mencapai kesuksesan dalam memimpin.

Sistem politik hukum yang bagaimanapun sifat dan bentuknya akan menampakkan pola tetap.Jika dikaitkan dengan studi ilmu komunikasi, maka dijumpai empat macam sistem komunikasi, yaitu sistem otoriter, sistem liberal, sistem tanggung jawab sosial dan sistem komunis (Almond, 1998: 61). Setiap sistem ini menampakkan karakter berbeda yang memberi warna dominan terhadap proses komunikasi sebagaimana implementasinya dalam partai politik, misalnya di Partai Keadilan Sejahtera (selanjutnya disingkat PKS) di Kabupaten Gowa, PKS.

Salah satu masalah terpenting yang menjadi perhatian khusus bagi masyarakat muslim Kabupaten Gowa, adalah masalah politik hukum. Dalam hal ini, maka PKS mengambil peran dalam pembinaan pemahaman politik hukum bangsa. Di Kab. Gowa PKS merupakan salah satu kekuatan politik yang dianggap masih memelihara dimensi etika dalam membangun politik. Atas dasar inilah, maka perlu dikaji lebih lanjut tentang urgensi implementasinya di Kabupaten Gowa.

Rumusan masalah dalam pepelitian ini seperti tertuang dalam paragraf berikut. Masalah pokok dalam penelitian ini: sejauhmana urgensi implementasi komunikasi politik hukum sangat penting dalam PKS Kabupaten Gowa? Adapun sub masalahnya sebagai berikut: Pertama, bagaimana eksistensi PKS dalam membangun komunikasi politik hukum di masyarakat Gowa? Kedua, faktot-faktor apa yang mempengaruhi PKS dalam memberikan pendidikan politik hukum masyarakat di Kabupaten Gowa?. Ketiga, bagaimana konstruksi etika komunikasi politik hukum PKS dalam pengembangan masyarakat di Kabupaten Gowa.

Adapun tujuan dan kegunaan penelitian ini bertuan untuk: pertama, mengetahui eksistensi PKS dalam mengembangkan komunikasi politik hukum khususnya pada masyarakat di kabupaten Gowa, karena terkait dengan pendidikan politik hukum yang sering menjadi masalah dalam pemilihan baik pemilihan legislatif maupun pemilihan eksekutif. Kedua, mendeskripsikan faktor-faktor yang mempengaruhi PKS sebagai partai dakwah dalam memberikan pencerahan kepada masyarakat di Kab. Gowa. Ketiga, memahami konstruksi etika komunikasi politik hukum yang dibangun oleh PKS dalam pengembangan politik di kalangan masyarakat muslim Kabupaten Gowa. 
ljtihad, Jurnal Wacana Hukum Islam dan Kemanusiaan, Volume 15, No. 1, Juni 2015: 21-38

Penelitian ini diharapkan berguna bagi ilmu pengetahuan dan memperkaya kajian komunikasi politikhukum secara umum, dan etika komuniasi politik hukum PKS secara khusus. Manfaat dalam bidang komunikasi adalah memperkaya kajian komunikasi khususnya dalam bidang komunikasi politik hukum, karena komunikasi adalah satu kajian tentang pesan baik yang disampaikan komunikator melalui media elektronik, cetak, maupun melalui lembaga-lembaga sosial keagamaan dan politik hukum.

Pada hakikatnya, manusia sejak lahir selalu ingin berkomunikasi, maka diharapkan penelitian ini akan memberikan stimulan kepada pelaku komunikasi untuk senantiasa menyampaikan komunikasi secara etik terutama para pelaku komunikasi politik hukum.

\section{Kajian teoretis: sejarah singkat dan visi-misi PKS}

PKS berdiri pada 20 Juli 1998 dengan nama awal Partai Keadilan (PK) dalam sebuah konferensi pers di Aula Masjid Al-Azhar, Kebayoran Baru, Jakarta (DPP-PKS, 2012: 2). Presiden (ketua) pertama partai ini adalah Nurmahmudi Isma'il. Pada 20 Oktober 1999, PK menerima tawaran kursi kementerian Kehutanan dan Perkebunan (Hutbun) dalam kabinet pemerintahan KH Abdurrahman Wahid, Nurmahmudi Isma'il pun ditunjuk untuk mengisi posisi tersebut. Nurmahmudi kemudian mengundurkan diri sebagai presiden partai dan digantikan oleh Hidayat Nur Wahid yang terpilih pada 21 Mei 2000.

Pemilu 1999, PK hanya berhasil mengumpulkan 1,4 juta suara pemilih. Meskipun perolehan ini mengantarkan PK memperoleh 7 kursi di DPR, PK tetap harus bersalin baju karena total suaranya tak mencapai batas electoral treshold (ET) 2 persen. Akibat UU Pemilu Nomor 3 Tahun 1999 tentang syarat berlakunya batas minimum keikut sertaan parpol pada pemilu selanjutnya (electoral threshold) dua persen, maka PK harus merubah namanya untuk dapat ikut kembali di Pemilu berikutnya.

Pada 2 Juli 2003, PK menyelesaikan seluruh proses verifikasi Departemen Kehakiman dan HAM (Depkehham) di tingkat Dewan Pimpinan Wilayah (setingkat Propinsi) dan Dewan Pimpinan Daerah (setingkat Kabupaten/Kota). Sehari kemudian, PK bergabung dengan PKS dan dengan penggabungan ini, seluruh hak milik PK menjadi milik PKS, termasuk anggota dewan dan para kadernya (Matta, 2012: 16). Dengan penggabungan ini maka PK resmi berubah nama menjadi PKS. Setelah Pemilu 2004, Hidayat Nur Wahid (Presiden PKS 
yang sedang menjabat) kemudian terpilih sebagai ketua MPR masa bakti 2004-2009 dan mengundurkan diri dari jabatannya sebagai Presiden PKS.

Pada Sidang Majelis Syuro I PKS pada 26 - 29 Mei 2005 di Jakarta, Tifatul Sembiring terpilih menjadi Presiden PKS untuk periode 2005-2010. Seperti Nurmahmudi Isma'il dan Hidayat Nur Wahid, disaat Tifatul Sembiring dipercaya oleh Susilo Bambang Yudhoyono sebagai menteri komunikasi dan informatika (Menkominfo), maka estafet kepemimpinan pun berpindah ke Luthfi Hasan Ishaq sebagai pjs Presiden PKS. Pada Sidang Majelis Syuro PKS II pada 16 - 20 Juni 2010 di Jakarta, Luthfi Hasan Ishaq terpilih menjadi Presiden PKS periode 2010-2015.

PKS mengusung visi umum sebagai partai dakwah penegak keadilan dan kesejahteraan dalam bingkai persatuan ummat dan bangsa. Sementara, visi khususnya adalah partai berpengaruh baik secara kekuatan politik, partisipasi, maupun opini dalam mewujudkan masyarakat Indonesia yang madani (DPP-PKS, 2012: 1).Visi ini akan mengarahkan PKS sebagai partai dakwah yang memperjuangkan Islam sebagai solusi dalam kehidupan berbangsa dan bernegara. Memerjuangkan kekuatan transformatif dari nilai dan ajaran Islam di dalam proses pembangunan kembali umat dan bangsa di berbagai bidang.

Misinya adalah, melahirkan kekuatan yang mempelopori dan menggalang kerjasama dengan berbagai kekuatan yang secita-cita dalam menegakkan nilai dan sistem Islam yang rahmatan lil alamin. Serta akselerator bagi perwujudan masyarakat madani di Indonesia. Pada misi, PKS mengusung 7 hal. Pertama, menyebarluaskan dakwah Islam dan mencetak kader-kadernya sebagai anashir taghyir. Kedua, mengembangkan institusi-institusi kemasyarakatan yang Islami di berbagai bidang sebagai markaz taghyir dan pusat solusi. Ketiga, membangun opini umum yang Islami dan iklim yang mendukung bagi penerapan ajaran Islam yang solutif dan membawa rahmat. Misi keempat, membangun kesadaran politik masyarakat, melakukan pembelaan, pelayanan dan pemberdayaan hak-hak kewarganegaraannya. Kelima, menegakkan amar ma'ruf nahi munkar terhadap kekuasaan secara konsisten dan kontinyu dalam bingkai hukum dan etika Islam (DPP-PKS, 2012: 2).

Dengan visi dan misi itu, maka PKS secara aktif melakukan komunikasi, silaturahim, kerjasama dan ishlah dengan berbagai unsur atau kalangan umat Islam untuk terwujudnya ukhuwah Islamiyah dan wihdatul-ummah, dan dengan berbagai komponen bangsa lainnya 
ljtihad, Jurnal Wacana Hukum Islam dan Kemanusiaan, Volume 15, No. 1, Juni 2015: 21-38

untuk memperkokoh kebersamaan dalam merealisir agenda reformasi. Terakhir, ikut memberikan kontribusi positif dalam menegakkan keadilan dan menolak kedhaliman khususnya terhadap negeri-negeri muslim yang tertindas.

\section{Konsep etika komunikasi}

Dalam komunikasi antar budaya, etika menyangkut nilai-nilai sosial dan budaya yang telah disepakati oleh suatu masyarakat tertentu sebagai norma yang harus dipatuhi. Karena itu perbedaan nilai antara suatu masyarakat dengan masyarakat lainnya tidak selalu sama, maka etika komunikasipun dapat pula berbeda (Efendi, 2004: 12). Suatu yang dianggap etis oleh dunia barat, mungkin saja dianggap suatu pelanggaran di dunia Timur, dan sebaliknya mungkin sesuatu yang dianggap etis bagi dunia timur dianggap pelanggaran bagi dunia barat, walaupun diakui banyak nilai-nilai atau etika yang berlaku secara universal.

Penilaian etis dalam peraktek komunikasi, tidak hanya pertimbangan baik dan buruk, tetapi harus menunjukkan patokan nilai standar yang menyatakan benar dan salah. Etika harus selalu ada dimana-mana dan kapan saja dalam hal mempengaruhi orang lain, dan hal itu tentunya juga harus selalu ada dalam komunikasi. Sebuah masyarakat tanpa etika adalah masyarakat yang menjelang kehancuran. Konsep dan teori dasar etika memberi kerangka yang dibutuhkan untuk melaksanakan kode etik atau moral setiap orang. Prinsip-prinsip etika adalah prasyarat keberadaan sebuah komunitas (Damsar, 2010: 56). Tanpa prinsipprinsip etika mustahil manusia bisa hidup harmonis dan tanpa ketakutan, kecemasan, keputusasaan, kekecewaan, pengertian dan ketidak pastian.

Etika komunikasi dalam implementasinya, selalu mendapat penilaian baik atau buruk. Dalam konteks Islam, nilai-nilai baik atau kebajikan yang harus dimunculkan, terutama bila merujuk pada batasan etika yang sepadan dengan akhlak sebagaimana yang disebutkan

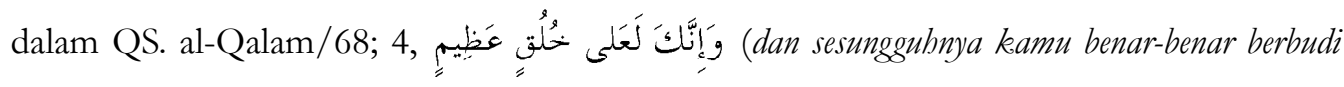
pekerti yang agung). Demikian pula dalam hadis Rasulullah saw bahwa (sesunggubnya tidaklah aku diutus melainkan untuk menyempurnakan akblak yang mulia).

Penilaian terhadap prilaku seseorang apakah etis atau tidak dalam melakukan komunikasi didasarkan pada tiga prinsip.Pertama, prinsip tentang apakah yang dapat dipakai sebagai 
dasar membuat kesusilaan.Kedua, prinsip tentang perbuatan apakah yang dikatakan betul, atau yang dibenarkan oleh kesusilaan. Ketiga, prinsip tentang makna apakah yang dikandung oleh kata seharusnya, dan apakah yang merupakan sumber wajib (Cangara, 2011: 8990).Ketiga prinsip ini memberi standar etika apa yang digunakan oleh komunikator dan komunikan dalam menilai komunikasi, baik dari segi isi, tujuan, maupun media yang digunakan dalam komunikasi.

\section{Nilai-nilai komunikasi politik hukum}

Politik hukum diartikan sebagai kebijakan dasar penyelenggara negara dibidang hukum yang sedang, dan akan berlaku, yang bersumber dari nilai-nilai yang berlaku di masyarakat untuk mencapai tujuan negara yang dicita-citakan (Syaukani, 2004: 23).

Suatu sistem politik biasanya mempunyai sekumpulan nilai serta prosedur terselubung dan terang-terangan dalam idiologinya yang dipandang sebagai suatu yang penting bagi pertumbuhan sistem pemerintahan. Jika nilai komunikasi sebagai sistem politik, maka nilai tersebut dapat digunakan sebagai kriteria untuk mengevaluasi etika komunikasi politik, cara dan tujuan berkomunikasi.

Komunikasi politik harus membentuk perwujudan nilai, dan bentuk komunikasi politik tersebut sangat dipengaruhi oleh suatu idiologi negara yang menganut idiologi otoritarian, suatu pemberitaan berada dalam tanggung jawab negara, sebab negara adalah ekspresi tertinggi dari suatu organisasi kelompok masyarakat, dan karena itu mestinya orang banyak adalah pemimpin karena dia mempunyai kesanggupan menganalisa dan mengumpulkan persoalan yang muncul dari kehidupan sosial masyarakat (Laswell, 1993: 10-11). Di negara lain mungkin menganut idiologi libertarian, karena itu mereka berasumsi bahwa manusia adalah mahluk ciptaan Tuhan, merupakan makhluk yang bermartabat yang otonomi dan mengikat dirinya pada prilaku etis tertentu.

Pola etika komunikasi politik seperti yang disebutkan, dalam aplikasi komunikasinya tentu berbeda, sebab disatu sisi otoritarian, komunikasi sangat ditentukan oleh negara dan siapa yang melanggar aturan negara, maka dianggap tidak etis dalam penyampaian pesannya. Di sisi lain libertarian yang dibutuhkan adalah tanggung jawab dan kejujuran dalam penyampaian informasi, sehingga informasi yang disampaikan tidak sekedar memenuhi 
ljtihad, Jurnal Wacana Hukum Islam dan Kemanusiaan, Volume 15, No. 1, Juni 2015: 21-38

keinginan komunikator, tetapi merupakan tanggung jawab moril dari suatu berita yang disampaikannya.

Proses komunikasi politik merupakan bagian integral dari proses perkembangan kepribadian manusia secara individual. Proses itu juga merupakan bagian yang utuh dan menyatu dengan proses perkembangan masyarakatnya, yang dalam proses terdapat lima unsur saling berkaitan sebagamana gambar berikut:

\section{Gambar 1. Unsur-unsur dalam proses komunikasi}

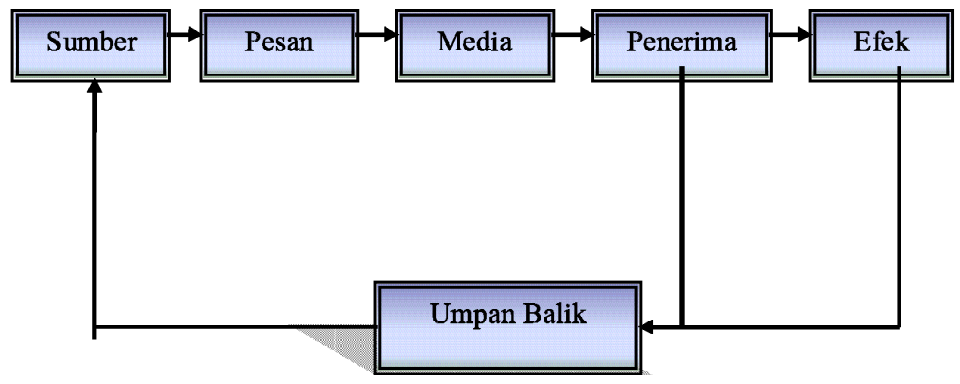

\section{Metode penelitian}

Penelitian ini dilaksanakan di Kabupaten Gowa sehingga tergolong dalam bentuk penelitian filed research dengan jenis kualitatif-naturalistic inquiry (inkuiri alamiah). Pendekatan yang digunakan adalah sosiologis-historis-politis. Ketiga pendekatan ini digunakan secara paralel tidak secara parsial.

Sumber data penelitian ini, pengurus dan anggota partai DPD PKS Kabupaten Gowa, yang dipilih secara purposive berdasarkan pertimbangan bahwa informan harus memiliki otoritas dan kompotensi untuk memberikan informasi atau data yang akurat dari suatu permasalahan yang diteliti. Data yang diperlukan dalam mendukung penyelesaian penelitian ini otomatis terkait dengan jenis-jenis sumbernya, seperti kepustakaan, yaitu kajian terhadap artikel-artikel atau buku-buku terkait dengan komunikasi politik PKS.

Metode pengumpulan data dalam penelitian ini, adalah observasi, wawancara dan dokumentasi. Data dalam penelitian ini diolah dengan menata secara sistematis catatan hasil pengamatan data tertulis dan data tidak tertulis, serta memprediksi hasil wawancara. Data 
yang telah terkumpul dideskripsikan sebagai temuan dalam laporan penelitian. Adapun prosedur pengolahan data selama di lapangan dianalisis secara interaktif dan berlangsung secara terusmenerus sampai tuntas, dengan kegiatan reduksi data, display data, verifikasi data.

Metode pengolahan data yang penulis temukan dari literatur-literatur diolah secara deduktif, induktif, dan komparatif.Keabsahan data dalam penelitian ini, dilakukan melalui tahap pengecekan kredibilitas data dengan teknik perssistent observasion, triangulasi (triangulation), member check, dan referential adequacy cheks.

\section{Hasil penelitian: deskripsi singkat lokasi penelitian}

Penelitian ini dilaksanakan di Kabupaten Gowa, salah satu daerah tingkat II di Propinsi Sulawesi Selatan, yang dominan penduduknya adalah suku Makassar. Wilayahnya, berada di daerah Selatan dari Sulawesi Selatan, di sebelah Utara berbatasan dengan Kota Makassar dan Maros. Di sebelah Timur berbatasan dengan Kabupaten Sinjai, Bulukumba dan Bantaeng. Di sebelah Selatan berbatasan dengan Kabupaten Takalar dan Jeneponto. Sedangkan di sebelah Baratnya berbatasan dengan Kota Makassar dan Takalar.

Kabupaten Gowa berada pada 12038.16' Bujur Timur dari Jakarta dan 5033.16' Bujur 'Timur dari Kutub Utara. Sedangkan letak wilayah administrasinya antara 12033.19' hingga 12015.17' Bujur Timur dan $5^{0} 5^{\prime}$ hingga $5^{0} 34.7^{\prime}$ Lintang Selatan dari Jakarta (BPS Gowa, 2010: 1).

Penyebutan Kabupaten Gowa sebagai daerah penelitian ini, belum begitu diketahui asalusul penamaannya. Kitab-kitab lontarak tidak mencatat apa sebab dan dari mana, serta bagaimana latarbelakang nama Gowa. Namun HD. Mangemba sebagaimana yang ditulis Syahrul Yasin Limpo mengutip beberapa pendapat antara lain bahwa, nama Gowa mungkin sekali berasal dari kata goari (bahasa Makassar) yang berarti kamar atau bilik. Pendapat lain, Gowa berasal dari kata goaria yang dapat diartikan sebagai suatu tempat atau ruangan berhimpun kaum pemburu. Pandangan lainnya lagi, Gowa berasal dari kata gua berarti liang di mana di sekitar itulah ditemukan hadirnya Tumanurunga ri Gowa (Raja Gowa Pertama), di Takabassia (Tamalate) (Limpo, 1996: 19-20).

Kemudian dalam catatan sejarah disebutkan bahwa, saat Indonesia merdeka, Kerajaan Gowa bergabung di dalamnya, namun beberapa tahun kemudian di saat tokoh-tokoh politik 
ljtihad, Jurnal Wacana Hukum Islam dan Kemanusiaan, Volume 15, No. 1, Juni 2015: 21-38

dan masyarakat merasa tidak puas atas masuknya Gowa ke dalam penguasaan Makassar dan sekitarnya, dan karena adanya tuntutan itu, maka Pemerintah Pusat dengan Undangundang Darurat Nomor 2 Tahun 1957 menetapkan Gowa sebagai kabupaten tersendiri (Tika, 2006: 80, dan dipimpin oleh seorang Bupati, saat ini adalah H. Ichsan Yasin Limpo, yang daerahnya ditinjau dari per-kecamatan terdiri atas 19 wilayah, yakni Bontonompo, Bontonompo Selatan, Bajeng, Bajeng Barat, Pallangga, Barombong, Somba Opu, Bontomarannu, Patallassang, Parangloe, Manuju, Tinggimoncong, Tombolo Pao, Parigi, Bungaya, Bontolempangan, Tompobulu, Biringbulu. Di setiap wilayah kecamatan ini ditemukan Pengurus Anak Cabang Partai Keadilan Sejahtera (PAC-PKS) yang menjadi obyek penelitian.

\section{Eksistensi PKS dalam membangun komunikasi politik hukum}

Partai Keadilan Sejahtera (PKS) di Kabupaten Gowa mulai berdiri sejak tahun 1998 dengan nama awal Partai Keadilan (disingkat PK). Ketua DPD PK saat itu adalah Nasaruddin, M.Pd.I, untuk tingkat DPW, propinsi adalah H. Najmudin S Mara Hamid, Lc, M.A. Pada pemilu 1999, PK berhasil merebut dua kursi di DPRD II Gowa (KPU Gowa, 2000). Anggota dewan PK, kemudian intens melakukan komunikasi politik beserta para kader PK, sehingga partai ini berkembang sampai berubah nama menjadi PKS pada tahun 2003. Saat penelitian ini berlangsung, yang menjabat sebagai ketua DPD PKS Gowa, adalah ustad Trie Alfiard Hasyim, dan sebagai sekretarisnya adalah ustad Wardoyo.

Bersamaan dengan penelitian berlangsung ditemukan data bahwa anggota DPRD Gowa dari PKS periode 2014-2019, sebanyak tiga orang, yakni Agussalim Nakku, H. Muhammadong Dg. Rate, dan H. Muh. Fitriandy. Keterangan yang diperoleh bahwa prilaku politik dalam pemilihan maupun simpatisan parpol PKS dapat dipengaruhi oleh tokoh dan ideologi yang ada dalam partai. Kader PKS lebih mengutamakan komunikasi lisan disertai dakwah bil hal yang merekrut suara rakyat (Wawancara, 10 September 2014). Selain itu, bagian penting dari komunikasi politik di interen PKS Kabupaten Gowa adalah meluncurkan program Taklim Rutin Kader (TRP).

Nasaruddin (Wawanacara, 6 September 2014) menyatakan bahwa TRP merupakan implementasi agenda kaderisasi rutin PKS Gowa dalam membangun komunikasi politik. Kegiatan ini dilksanakan sejak tahun 2010 sampai sekarang dan merupakan agenda yang bersifaat 
wajib bagi semua kader baik pengurus maupun yang tidak. Kegiatan ini bertujuan memberikan pemahaman yang seutuhnya tentang dakwah dan politik Islam kepada seluruh kader. Sebagai partai kader dan partai dakwah sudah semestinya akan sangat konsen dalam masalah kaderisasi dan dakwah. Implementasi dari hal tersebut, berdasarkan observasi penulis maka PKS di Kabupaten Gowa selalu melakukan pembinaan secara rutin dan berkala untuk para kadernya.

Observasi penulis menunjukkan bahwa di tengah-tengah masyarakat, aktivis dakwah yang dilakukan para kader PKS Kabupaten Gowa belakangan ini memperlihatkan peningkatan yang cukup mengembirakan, bertambahnya kader dari berbagai kalangan tidak lepas dari usaha yang dilakukan elit partau.

Arif Prihandono Sukarto (Wawancara, 11 September 2014) menyatakan, mobilisasi dakwah PKS Gowa selama ini tidak selamanya dilakukan para ikhwan saja tetatpi juga kader akhwat yang juga tidak mau kalah, mereka melakukan aktifitas dakwah dengan penuh semangat, melalui program mereka, bidang kewanitaan DPD PKS Kabupaten Gowa yang di ketuai oleh Ibu Hadiyah dengan program PWK (Posko Wanita Keadilan)nya dengan koordinator Ibu Asamawati (Asda) mereka melakuakan aktifitas di berbagai tempat yang tentunya program seperti ini berhubungan dengan kegiatan komunikasi politik bagi kaum perempuan.

Lebih lanjut observasi penulis di lapangan menunjukkan bahwa PWK telah terbentuk di beberapa DPC pada tingkat kecamatan dan telah melaksankan program-program mereka, seperti majelis taklim, Baksos Kewanitaan,dan Masih banyak lagi aktifivas yang telah dilakukan dalam upaya menggerakkan komunikasi politik.

PWK di internal PKS merupakan program tersendiri yang bersentuhan langsung dengan masyarakat utamanya kaum ibu-ibu maka dari itu para anggota yang tergabung dalam PWK ini tidak menutup kemungkinan haruslah anggota atau kader dari PKS sendiri, tetapi masyarakat luaspun boleh bergabung di PWK ini. Dengan PWK, diharapkan menjadi ajang untuk menyalurkan aspirasi politik dari para kader-kader akhwat, yakni kaum perempuan di lingkungan PKS.

Berdasarkan data dan keterangan disebutkan di atas, dipahami bahwa dalam komunikasi politik PKS di Kabupaten Gowa, bersentuhan ke masayarakat bawah sebagai basis, demikian pula persekutuan antar elite partai dan bukan partai terjalin dengan mengangkat issu dakwah dan politik berdasarkan ajaran Islam. 
ljtihad, Jurnal Wacana Hukum Islam dan Kemanusiaan, Volume 15, No. 1, Juni 2015: 21-38

\section{Faktor-faktor yang mempengaruhi PKS dalam memberikan pendidikan politik}

Untuk memahami faktor-faktor yang mempengaruhi perilaku politik masyarakat, terurama faktor yang mempengaruhi PKS dalam memberikan pendidikan masyarakat di Kabupaten Gowa, dapat diketahui melalui beberapa persepsi yang dalam observasi penulis, diketahui bahwa pada level pemilih muncul sentimen-sentimen agama yang tidak lagi menjadi faktor penting dalam menentukan pilihan mereka. Ini bisa terlihat jelas dalam pemilihan legislatif di Kabupaten Gowa. Bagi pemilih muslim ternyata faktor agama tidak begitu penting dalam menentukan pilihan politik, dengan kata lain bahwa faktor agama setidaknya tidak sepenting yang diharapkan oleh kelompok-kelompok tertentu.

Dalam perspektif politik modern, masyarakat muslim di Kabupaten Gowa ini sudah semakin modern, karena tidak membuat politik diperumit oleh persoalan agama. Soal politik berjalan sangat dinamis, tidak harus dicampuradukkan dengan hal-hal yang sifatnya permanen dan abadi. Dalam pandangan penulis,seharusnya memang begitu dalam politik modern, karena tergantung bagaimana masyakarat melihatnya.Tetapi jika dilihat dari sudut pandang kelompok yang tidak mau memisahkan antara agama dan politik, gejala ini adalah gejala kemunduran bagi partai yang berlabel Islam seperti PKS.

Menurut Ahmad Baco (Wawancara, 10 September 2014), ada tiga faktor yang mempengaruhi untuk memilih atau tidak memilih dalam Pemilu dalam indoktrinasi PKS.Pertama, identitas partai, dimana semakin solid dan mapan suatu partai politik maka akan memperoleh dukungan yang mantap dari para pendukungnya begitu pula sebaliknya. Kedua, kemampuan partai dalam menjual isu kampanye. Partai status quo biasanya menjual isu-isu kemapanan dan keberhasilan yang telah mereka raih. Partai-partai politik baru biasanya menjual isu-isu "menarik" dan partai politik tersebut biasanya dianggap "bersih" terutama dari nuansa money politics. Ketiga, penampilan kandidat, dimana performa kandidat sangat menentukan keberhasilan kandidat.

Dalam kaitan itu, maka identifikasi partai merupakan identifikasi psikologis individu terhadap suatu partai politik, berupa sikap dan kedekatan dengan partai politik, dapat bersifat menetap, dan sangat fundamental dalam mempengaruhi perilaku politik individu. Dengan ini, maka PKS di Kabupaten Gowa lebih mengutamakan kedekatan emosional masyarakat muslimterhadap partai. Hal lain adalahmember keyakinan-keyakinan terhadap masyarakat muslim bahwa PKS merupakan partai politik Islami, sehingga masyarakat muslim merasa 
menjadi bagian (sense of belonging) dari PKS.

Berkaitan dengan itulah, untuk lebih memahami faktor-faktor yang mempengaruhi perilaku politik masyarakat, penulis dapat menjabarkannya sebagai berikut:

Pertama, perlu dipahami dalam konteks latar belakang historis. Sikap dan perilaku politik masyarakat dipengaruhi oleh proses-proses dan peristiwa histories masa lalu. Hal ini disebabkan bahwa budaya politik tidak merupakan kenyataan yang statis dan tidak berkembang, tetapi justru sebaliknya merupakan sesuatu yang berubah dan berkembang sepanjang masa.

Kedua, faktor kondisi geografis memberikan pengaruh dalam perilaku politik masyarakat sebagai kawasan geostrategis, seperti Kabupaten Gowa memiliki kemungkinan sebagai pusat perhatian dunia internasional. Wilayah geografis yang strategis merupakan pertimbangan strategis untuk mengadakan kerja sama dan hubungan dalam berbagai kepentingan. Di pihak lain, faktor kemajemukan budaya dan etnis merupakan hal yang rawan bagi terciptanya desintegrasi.

Ketiga, faktor budaya politik memiliki pengaruh dalam perilaku politik masyarakat. Budaya politik suatu bangsa merupakan distribusi pola-pola orientasi khusus menuju tujuan politik, mencapai serta memelihara stabilitas sistem politik. Berfungsinya budaya politik itu pada prinsipnya ditentukan oleh tingkat keserasian antara kebudayaan bangsa dan struktur politiknya.

Keempat, pendidikan dan komunikasi juga mempengaruhi perilaku politik seseorang. Sistem politik yang cenderung sentralistis akan mempengaruhi perilaku politik seseorang dalam mengatasi dan mengakomodasi berbagai kepentingan. Semakin tinggi pendidikan masyarakat maka semakin tinggi tingkat kesadaran politiknya, dan sebaliknya, semakin rendah tingkat pendidikan maka semakin rendah pula tingkat kesadaran politiknya. Komunikasi politik yang intens akan mempengaruhi perilaku politik seseorang dalam kegiatan politiknya.

Kelima, faktor kepribadian seseorang juga mempengaruhi perilaku politik. Perilaku politik itu bergantung pada sifat struktur kepribadian yang dimilikinya, apakah tergolong dalam fungsi penyesuaian diri atau dalam basis fungsional eksternalisasi dan pertahanan diri.

Keenam, faktor lingkungan sosial politik. Faktor ini dapat mempengaruhi aktor politik secara langsung seperti keadaan keluarga, cuaca, keadaan ruang, ancaman, suasana kelompok dan kehadiran orang lain. Lingkungan sosial politik tersebut saling mempengaruhi dan berhubungan satu dengan yang lain dan bukannya sebagai faktor yang berdiri sendiri. Melalui proses, pengalaman, sosialisasi dan sebgainya terbentuklah sikap dan perilaku politik seseorang. 
ljtihad, Jurnal Wacana Hukum Islam dan Kemanusiaan, Volume 15, No. 1, Juni 2015: 21-38

\section{Konstruksi etika komunikasi politik hukum PKS dalam pengembangan masyarakat}

Konstruksi etika dalam komunikasi politik hukum merupakan standar moral yang mengatur perilaku tentang bagaimana bertindak dan mengharapkan orang lain bertindak. Etika dalam komunikasi politik hukum PKS sebagaimana yang disebutkan Ahamdi Ahmad, merupakan dialektika antara kebebasan dan tanggungjawab, antara tujuan yang hendak dicapai dan cara untuk mencapai tujuan itu. Ia berkaitan dengan penilaian tentang perilaku benar atau tidak benar, yang baik atau tidak baik, yang pantas atau tidak, yang berguna atau tidak berguna, dan yang harus dilakukan atau tidak boleh dilakukan. Dalam kaitan ini, menurut Ahmadi Ahmad (Wawancara, 12 September 2014) maka PKS lebih mengutamakan etika komunikasi dakwah dalam bentuk kegiatan tarbiyah. Dengan demikian, kegiatan dakwah yang implementasi melalui pengkaderan dalam bentuk tarbiyah menjadi urgen di PKS.Kegiatan tersebut dijadikan sebagai wahana pembentukan karakter yang dapat merekonstruksi etika komunikasi politik hukum bagi kader-kader PKS.

Dalam pandangan Taufan Abdul Salam (Wawancara, 10 September 2014), paradigma konstruktivis etika komunikasi politik hukum, merupakan fenomena sosial yang dipahami sebagai suatu realitas dan telah dikonstruksikan. Karenanya, PKS Kabupaten Gowa berusaha berkonsentrasi menganalisis pada paradigma konstruksionis untuk menemukan peristiwa atau realitas hukum tersebut dikonstruksi dalam rangka pengembangan masyarakat melalui kegiatan dakwah dengan mengintensifkan komunikasi politik hukum yang Islami. Dalam pandangan penulis bahwa hal ini tidak lain adalah produk dakwah yang harus dikembangkan secara terus-menerus agar mempunyai aksi dan pengaruh signifikan.

Berdasarkan observasi penulis, PKS Kabupaten Gowa lebih menekankan implementasi etika komunikasi dakwah dengan cara mendekati masyarakat sehingga terwujud etika komunikasi insani bersifat relatif, artinya hanya berlaku untuk masyarakat di kabupaten Gowa tersebut dan tidak mengikat masyarakat-masyarakat lainnya. Ini dikarenakan PKS memiliki definisi tersendiri mengenai konsep kebenaran, rasionalitas, objektivitas, kesopanan, penghinaan, kebebasan, tanggung jawab atau kebohongan secara berlainan pula. Dengan begitu, maka etika komunikasi bagi PKS di Kabupaten juga didasari pada kenyataan bahwa komunikasi terdiri dari berbagai konteks. Ada komunikasi antarpersona, komunikasi kelompok kecil, komunikasi publik, komunikasi organisasi, komunikasi massa dan komunikasi budaya. Etika komunikasi tidak 
menjadi muskil bagi PKS di Kabupaten Gowa karena telah menerapkan suatu standar untuk semua situasi komunikasi, pada setiap waktu dan dalam setiap kegiatan tarbiyah.

Pendekatan atau perspektif situasional dalam menerapkan kajian mengenai etika komunikasi insan bagi PKS di Kabupaten Gowa, dalam konteks situasi yang berbeda, maka diketahui sisi dalam individu yang sebut saja sebagai “diri”, yakni subjek sang "aku” dalam individu seseorang yang senantiasa dihadapkan pada situasi pencarian jati diri atau identitasnya. Hal ini merujuk pada wacana filsafat klasik yang menyoal seputar "siapakah aku manusia" mencatat nama besar Descartes yang merumuskan "diri” sebagai sang aktor pelaku yang dengan "cogito"-nya menentukan lakunya.

Catatan tentang proses menjadi diri seseorang seperti yang disebutkan di atas sengaja ditampilkan karena menurut Taufan Abdul Salam HS Daeng Gassing (Wawancara, 10 September 2014) bahwa PKS memiliki keterkaitan dengan persoalan keputusan yang harus diambil dalam menentukan suatu perilaku ketika berada dalam suatu konteks lingkungan atau situasi tertentu, atau berkaitan dengan persoalan mendasar penilaian etika komunikasi insani. Dalam kaitan ini, maka dalam mempersoalkan etika komunikasi sesungguhnya memasuki wilayah yang abstrak karena komunikasi dalam sebuah partai terkadang tidak diketahui oleh pihak lain, atau partai lain. Umumnya seseorang menilai etika komunikasi pada suatu partai berdasarkan niat yang dimiliki. Namun ketika menilai etika komunikasi orang lain, terkadang menilai etika komunikasi mereka berdasarkan tindakan-tindakan mereka yang kasat mata. Masalahnya, niat yang sama mungkin diwujudkan lewat tindakan yang berbeda, atau tindakan yang sama mungkin berdasarkan niat yang berbeda. Dengan kata lain, ketika seseorang melakukan penilaian terhadap etika komunikasi seseorang berarti telah menimbang antara sisi dalam dan sisi luar. Sisi dalam adalah niat atau intensi sedangkan sisi luar adalah wujud tindakan. Masalahnya, antara niat dan perwujudan itu ternyata tak selalu berjalan lurus.

Selain adanya kemungkinan tidak konsistennya antara sisi luar dan sisi dalam dari tindakan seseorang seperti di atas, penilaian etika komunikasi makin tidak mudah karena juga harus berhadapan dengan kenyataan bahwa dalam diri seseorang rupanya senantiasa ada ketegangan antara seseorang memiliki kemampuan untuk melihat dirinya sekaligus sebagai subjek dan objek. Diri seseorang bersifat reflektif, dalam arti seseorang bisa melihat dirinya sebagaimana 
ljtihad, Jurnal Wacana Hukum Islam dan Kemanusiaan, Volume 15, No. 1, Juni 2015: 21-38

tercermin dalam gambaran orang lain terhadap diri orang lain.

Untuk tataran implementasinya, komunikasi politik hukum yang dilakukan oleh PKS di Kabupaten Gowa memang lebih aktif, ini ditandai dengan intensnya silaturahmi pada sejumlah elit partai dan juga tokoh politik serta permuka agama yang dianggap potensial dalam melakukan propaganda di masyarakat. Pelaksanaa komunikasi politik hukum di internal dalam penentuan calon, baik legislatif, eksekutif maupun pimpinan partai melalui musyawarah dan kemudian mempromosikannya melalui sosialisasi kader ketingkat pengurus dari tingkat Kabupaten sampai ke desa-desa.

Dalam kenyataannya, PKS Kabupaten Gowa dalam komunikasi politik hukumnya bersinergi dengan partai lain, khususnya dalam menganalisa pelaksanaan program pemerintah. Dalam proses komunikasi politik hukum langsung dengan masyarakat yang kemudian menghasilkan beberapa program unggulan dari calon PKS antara lain, program kesehatan gratis dengan hanya menujukkan KTP yang dikhususkan untuk masyarakat menengah ke bawah karena prihatin dengan pelayanan kesehatan yang tidak terjangkau bagi masyarakat menengah kebawah padahal sudah tersedia dana untuk itu, Pendidikan Gratis yang memang banyak diserukan oleh calon dari partai lain, dan PKS konsen pada pendidikan wajib belajar sembilan tahun.

Selanjutnya ada program perbaikan sarana dan prasarana yang memang dibuat berdasarkan dialog langsung antara elit PKS dengan masyarakat di Kabupaten Gowa yang menginginkan sarana dan prasarana yang ada memadai hingga masyarakat dapat mempergunakan fasilitas umum seperti jalan, sekolah, rumah sakit, rumah ibadah, dan lain sebagainya. Selain sarana dan prasarana yang memadai, membangkitkan usaha kecil menengah (UKM) melalui RT/ RW untuk mengurangi angka pengangguran di Kabupaten Gowa sekaligus menciptakan lapangan kerja agar dapat meningkatkan tingkat ekonomi masyarakat menengah ke bawah.

Program yang terakhir adalah religius dan berbudaya, religius memang menjadi ciri utama PKS dalam melakukan komunikasi politik baik internal maupun eksternal partai. Sebagai partai Islam PKS selalu mengedepankan cara Islam dalam setiap langkah komunikasi politik hukumnya namun tetap disesuaikan dengan perkembangan jaman dan juga kultur sosial yang berlaku di masyarakat. Berbudaya yang dimaksud adalah melestarikan nilai-nilai kebudayan masyarakat di Gowa yang ramah dan santun juga tidak meninggalkan norma sosial yang masih ditunjung tinggi hingga sekarang ditengah serbuan budaya barat yang 
banyak diaplikasi oleh kaum muda dan tidak memahami tentang adat ketimuran yang santun dan tetap ada batasan dalam berbagai hal.

\section{Penutup}

Kesimpulan dari penelitian ini pertama, eksistensi PKS digambarkan dalam Visi Misi, dan Tujuan pendirian PKS. Untuk di Kabupaten Gowa walaupun belum maksimal raihan keterpilihan oleh Masyarakat, tetapi sudah menjadi perhatian bagi sebagian masyarakat terutama mereka yang mendambakan nilai-nilai Islam dalam perjuangan partai.

Kedua, ada tiga faktor yang mempengaruhi untuk memilih atau tidak memilih dalam Pemilu.Pertama, identitas partai, dimana semakin solid dan mapan suatu partai politik maka akan memperoleh dukungan yang mantap dari para pendukungnya begitu pula sebaliknya. Kedua, kemampuan partai dalam menjual isu kampanye. Partai status quo biasanya menjual isu-isu kemapanan dan keberhasilan yang telah mereka raih. Partai-partai politik baru biasanya menjual isu-isu "menarik" dan partai politik tersebut biasanya dianggap "bersih" terutama dari nuansa money politics. Ketiga, penampilan kandidat, dimana performa kandidat sangat menentukan keberhasilan kandidat.

Ketiga, etika komunikasi yang dibangun oleh PKS di Kabupaten Gowa meliputi etika komunikasi dengan elit partai sendiri, yakni didasarkan pada anggaran dasar dan anggran rumah Tangga PKS, sedang hubungannya dengan masyarakat dan anggota dibangun dengan melalui berbagai kegiatan baik dalam kaitannya dengan pembangunan ekonomi maupun yang berkaitan dengan pengamalan agama melalui tarbiyah, sedang kaitannya dengan struktural pemerintahan, legislatif, dan partai lain dilakukan dengan mengikuti rambu-rambu kesepakatan dan atau aturan yang belaku pada setiap elemen tersebut.

Adapun implikasi dari penelitian ini, PKS sebagai partai Islam yang lebih mengutamakan kegiatan komunikasi dakwah memiliki ciri khas politik yang berdasarkan ajaran Islam, yang berimplikasi pada upaya untuk memaksimalkan hasil yang dicapai oleh partai politik dalam perjuangan partai. Dalam kaitan ini disarankan perlunya perumusan lebih lanjut tentang pola hubungan yang dibangun diantara berbagai elemen masyarakat, sehingga tercapai tujuan yang dicita-citakan. 
ljtihad, Jurnal Wacana Hukum Islam dan Kemanusiaan, Volume 15, No. 1, Juni 2015: 21-38

\section{Daftar pustaka}

Almond,Gabriel. Comparative Politics: System, Proes, and Policy. New York: Harper \& Co, 1998.

Dewan Pimpinan Pusat Partai Keadilan Sejahtera. Anggaran Dasar dan Anggaran Rumah Tangga PKS., t.pt: tp, 2012.

Badan Pusat Statistik Kabupaten Gowa. Gowa dalam Angka: Gowa In Figures. Gowa: BPS Gowa dan Bappeda Gowa, 2010.

Cangara, Hafied. Komunikasi Politik: Konsep, Teori, dan Strategi. Jakarta: Rajawali Pers, 2011.

Cangara, Hafied. Pengantar Ilmu Komunikasi. Jakarta: Raja Grapindo Persada, 2008.

Damsar. Pengantar Sosiologi Politik. Jakarta: Kencana Prenada Media Group, 2010.

Depari, Edwar. Komunikasi Politik Pembangunan.Jakarta: Bina Aksara, 2005.

Ibnu Khaldun, Muqaddimah diterjemahkan oleh Ahmad Toha dengan Judul Mukaddimah Ibnu Khaldun, Jakarta: Pustaka Pirdaus, 1996.

Komisi Pemilihan Umum (KPU) Kabupaten Gowa. "Daftar nama-nama Anggota Dewan dalam "Pengumuman" Gowa. Komisi Pemilihan Umum (KPU) Kabupaten Gowa, 2000 .

Lasswell, H.D. The Structure and Function of Communication in Society, L. Bryson (ed.) The Communication of Ideas. New York: Harper \& Co, 1993.

Matta, Anis. Partai Keadilan dalam Mensejabterakan Rakyat: Sebuah Solutif bagi PKS. Jakarta: Sekjen DPP PKS, 2012.

Matta, Anis. Partai Keadilan: Sebuah Solusi dalam Membesarkan Partai. Jakarta: Sekjen DPP PKS, 2013.

Moleong,Lexy J. Metodologi Penelitian Kualitatif. Bandung: PT. Remaja Rosda Karya, 2005.

Nata, Abuddin. Metodologi Studi Islam, Cet. III. Jakarta: PT Raja Grafindo Persada, 2009.

Nimno. Komunikasi Politike komunikator, Pesan dan Media. Bandung:Remaja Karya, 2000.

Strauss, Anselm dan Juliet Corbin, Dasar-dasar Penelitian Kualitatif: Tatalangkah dan Teknikteknik Teoritisasi Data. Yogyakarta: Pustaka Pelajar, 2003.

Syaukani, Imam dan A. Ahsin Thohari. Dasar-dasar Politik Hukum. Jakarta: PT Raja Grafindo Persada, 2004.

Tika, Zainuddin. M. Ridwan, Rosdiana Z. Profil Raja-raja Gowa. Sungguminasa: Perusda Karya Gowa, 2006.

Wijaya, A.W. Imu Komunikasi Teori dan Peraktek. Jakarta: Bina Aksara, 2006

Wijaya, A.W. Komunikasi Hubungan Masyarakat. Jakarta: Bina Aksara, 2003.

Yasin Limpo, Syahrul. Profil Sejarah: Budaya dan Pariwisata Gowa. Sungguminasa Gowa: Pemda Gowa bekerjasama dengan Yayasan Eksponen, 2006. 